\title{
A New Strain of Sweet Potato Feathery Mottle Virus That Causes Russet Crack on Fleshy Roots of Some Japanese Cultivars of Sweet Potato
}

\author{
Tomio Usugi*, Masaaki NAKAnO**, Masatoshi OnUKI***, \\ Tetsuo MAOKA* and Takaharu HAYASHI****
}

\begin{abstract}
A new filamentous virus (designated $\mathrm{VC}$ ) was isolated from sweet potato plants that seemed to be tolerant to russet crack. It infected Ipomoea spp., Chenopodium quinoa and $C$. amaranticolor. Ipomoea nil infected with the virus developed typical vein-clearing on the first true leaf. The infectivity of VC in sap was lost at dilutions between $1: 10,000$ and 1 : 100,000 and after storage for one day at $20^{\circ} \mathrm{C}$. Its thermal inactivation point was between 50 and $60^{\circ} \mathrm{C}$, and virus particles were $850-880 \mathrm{~nm}$ long and $13 \mathrm{~nm}$ wide. VC was nonpersistently transmitted by the aphid Myzus persicae, and was serologically related but not identical to sweet potato feathery mottle virus (SPFMV, abbreviated as Mo) that belongs to Potyvirus. Coat proteins of both purified VC and Mo migrated as three major bands of proteins with $\operatorname{Mr} 32,000,30,000$ and 29,000. However, electro-blot immunoassay revealed one major protein of $\mathrm{Mr} 38,000$ and an additional, more slowly migrating protein of $\mathrm{Mr}$ 97,000 in leaves infected with VC, and one major protein of Mr 38,000 in leaves infected with Mo. Sweet potato inoculated with VC developed symptoms of russet crack on the fleshy roots. These results indicate that $\mathrm{VC}$ is the causative agent of russet crack that occurs in some Japanese cultivars of sweet potato and that VC is a new strain of SPFMV. Therefore, we named VC and Mo severe strain (SPFMV-S) and ordinary strain (SPFMVO), respectively, of SPFMV.
\end{abstract}

(Received September 13, 1993)

Key words: sweet potato feathery mottle virus, severe strain (SPFMV-S), ordinary strain (SPFMV-O), russet crack.

\section{INTRODUCTION}

In a previous paper we reported the isolation of sweet potato feathery mottle virus (SPFMV, abbreviated as Mo) and sweet potato latent virus (SPLV), both of which belong to Genus Potyvirus, and sweet potato symptomless virus (SPSV) from sweet potato [Ipomoea batatas (L.) Lam.] that was affected with russet crack, known as "Obizyo-sohi" in Japanese ${ }^{5,15,18)}$. However, none of these viruses caused the disease when inoculated to virus-free sweet $\operatorname{potato}^{18)}$. Therefore, we conducted a further investigation to identify the causative agent of the disease.

* Japan International Research Center for Agricultural Sciences, Okinawa Sub-Tropical Station, Ishigaki, Okinawa 907, Japan国際農林水産業研究センター沖縄支所

** Agriculture, Forestry and Fisheries Research Council Secretariat, Chiyoda-ku, Tokyo 100, Japan 農林水産 技術会議

*** Kyushu National Agricultural Experiment Station, Nishigoushi, Kikuchi-gun, Kumamoto 861-11, Japan 九 州農業試験場

**** Japan International Research Center for Agricultural Sciences, Tsukuba, Ibaraki 305, Japan

国際農林水産 業研究センター 
A new filamentous virus was isolated from sweet potato which seemed to be tolerant to russet crack. The virus had properties similar to, but slightly different from Mo in terms of symptomatology of Ipomoea nil and serology. This virus caused typical symptoms of russet crack on the virus-free fleshy roots of sweet potato (cv. Kotobuki No. 1) when inoculated.

In this report, we describe the experimental results of isolation, characterization and purification of the virus, as well as its serology and the effects of inoculation of virus-free sweet potato.

Preliminary reports of this work were presented at the Annual Meeting of the Phytopathological Society of Japan in $1990^{16)}$ and $1992^{17)}$.

\section{MATERIALS AND METHODS}

Source and inoculation of the virus. Fleshy roots of sweet potato with red skin (cv. unknown), which did not exhibit any symptoms of russet crack in spite of long-term cultivation outdoors, were kindly supplied by R. Nagata. Lower leaves of the sweet potato served as the initial source of virus and the isolate was later designated VC. Sap inoculation was performed as described previously ${ }^{18}$. The inoculated plants were kept under greenhouse conditions at $26^{\circ} \mathrm{C}$ or higher temperature unless otherwise stated.

Mo, SPLV and SPSV used in this experiment were described elsewhere ${ }^{18)}$.

Stability of the virus in sap. Stability of the virus in the sap of infected I. nil (cv. Scarlet O'Hara) was determined by the method reported previously ${ }^{18)}$.

Aphid transmission. Aphid transmission tests were performed in a greenhouse using Myzus persicae collected from sweet potato and reared on Chinese cabbage (Brassica campestris L.). Apterous aphids were starved for 1-2 $\mathrm{hr}$ and then allowed an acquisition feeding for 3-5 min on leaves of infected I. nil. After the test period for 2-3 min, the aphids were killed by spraying an insecticide.

Purification. About $90 \mathrm{~g}$ of the infected fresh leaf tissues of $I$. nil were ground with $270-360 \mathrm{ml}$ of $0.1 \mathrm{M}$ sodium citrate that contained $0.1 \%$ thioglycolic acid, $\mathrm{pH}$ 6.5. The extract was squeezed through one layer of gauze and emulsified with 7\% 1-butanol for $15 \mathrm{~min}$. After centrifugation for $15 \mathrm{~min}$ at $15,000 \times g$ (maximum), the supernatant was filtered through one layer of gauze. The filtrate was subjected to centrifugation at $142,800 \times g$ (maximum) for $60 \mathrm{~min}$ in an RP 42 rotor (Hitachi Koki Co., Ltd., Katsuta, Japan). The resulant pellet was resuspended in $13.5 \mathrm{ml}$ of the same buffer and the suspension was centrifuged at $12,000 \times \mathrm{g}$ (maximum) for $15 \mathrm{~min}$. Then, $4.995 \mathrm{~g}$ of cesium chloride were added to 13.5 $\mathrm{ml}$ of the supernatant and dissolved. The mixture was equally divided into three tubes and then centrifuged at $55,000 \mathrm{rpm}$ for $8 \mathrm{hr}$ or $35,000 \mathrm{rpm}$ for $16 \mathrm{hr}$ in an RPS 65T rotor (Hitachi). The resultant opalescent band was collected from each tube with a syringe, and the virus was concentrated by ultracentrifugation. The pellet was resuspended in $0.01 \mathrm{M}$ phosphate buffered saline, pH 7.0 (PBS).

Serology. A rabbit was injected intramuscularly with a preparation of purified virus, emulsified with an equal volume of complete Freund's adjuvant, on three occasions at about 20-day intervals. The serological relationship among viruses was examined by complement fixation tests. Serologically specific electron microscopy using protein A-gold (SSEM-PAG) was performed as described by Usugi et $a l .{ }^{18)}$

Electrophoretic analysis of coat proteins. Purified virus particles, resuspended in $50 \mu 1$ of PBS, were mixed with $50 \mu 1$ of sample buffer and $25 \mu 1$ of a $0.5 \%$ solution of bromophenol blue. The mixture was boiled at $100^{\circ} \mathrm{C}$ for $5 \mathrm{~min}$. The sample buffer consisted of $0.125 \mathrm{M}$ Tris- $\mathrm{HCl}(\mathrm{pH} 6.8), 4 \%$ SDS, $20 \%$ glycerol and 10\% mercaptoethanol. Samples were subjected to electrophoresis at $20 \mathrm{~mA} / \mathrm{gel}$ for $90 \mathrm{~min}$ on a $5 \%$ and $15 \%$ discontinuous polyacrylamide slab gel $(85 \times 85 \times 1 \mathrm{~mm})$ that contained $0.1 \%$ SDS, as desdribed by Laemmli ${ }^{8}$. After electrophoresis, the gel was stained with Coomassie brilliant blue $\mathrm{R}(\mathrm{CBB})$.

Electro-blot immunoassay. A leaf homogenate was prepared by grinding leaf tissues with 10 volumes of $0.1 \mathrm{M}$ phosphate buffer ( $\mathrm{pH} 7.0$ ) and then filtering the homogenate through absorbent cotton. The filtered homogenate was then mixed with sample buffer, heated and subjected to electrophoresis as described above. Polypeptides were then electrophoretically transferred to Clear Blot Membrane-p 
(AE-6660 ; Atto Corp., Tokyo) at $2 \mathrm{~mA} / \mathrm{cm}^{2}$ for $1 \mathrm{hr}$ using an apparatus (AE-6675P/N) from Atto.

After electro-blotting, the blotted sheet was soaked in a 1\% solution of gelatin in $20 \mathrm{mM}$ Tris- $\mathrm{HCl}$, $500 \mathrm{mM} \mathrm{NaCl}, \mathrm{pH} 7.5$ (TBS) and kept in a refrigerator overnight. Then, it was incubated for $2 \mathrm{hr}$ in the virus specific antiserum absorbed by healthy $I$. nil sap, which was diluted $1: 2,000$ with a homogenate prepared by grinding the leaf tissues of a healthy $I$. nil plant with 10 volumes of TBS plus $0.05 \%$ Tween 20 (TBS-T) and was centrifuged for 5 min at $15,000 \times g$. The sheet was washed with TBS- $T$ for 30 min and then treated for $1 \mathrm{hr}$ with alkaline phosphatase-conjugated protein A (ZYMED Laboratories, Inc., San Francisco, CA) diluted 1:1,500. The sheet was washed with TBS-T for $30 \mathrm{~min}$ and incubated in the substrate solution for $10 \mathrm{~min}$ or longer. The substrate solution consisted of $6 \mathrm{ml}$ of $0.33 \mathrm{mg} / \mathrm{ml}$ nitro blue tetrazolium in $0.1 \mathrm{M}$ Tris- $\mathrm{HCl}, 0.1 \mathrm{M} \mathrm{NaCl}, 5 \mathrm{mM} \mathrm{MgCl}$, pH 9.5 plus $10 \mu 1$ of a solution of $100 \mathrm{mg} / \mathrm{ml}$ 5-bromo-4-chloro-3-indolylphosphate $p$-toluidine salt in $\mathrm{N}, \mathrm{N}$-dimethylformamide. Each solution was prepared just before use. When sufficient color had developed, the sheet was transferred to the stop solution (10 mM Tris-HCl, 5 mM EDTA, pH 7.5) and dried.

Inoculation to sweet potato. Virus-free sweet potato (cv. Kotobuki No. 1) was inoculated by grafting with infected $I$. nil and kept in a greenhouse controlled at above $18^{\circ} \mathrm{C}$ at Kyushu National Agricultural Experiment Station, Chikugo City, Fukuoka Prefecture. The vines of sweet potato were planted in a field, covered with cheesecloth, on 13th June 1989 and the fleshy roots were examined on 30th September 1989.

\section{RESULTS}

\section{Isolation of virus from sweet potato}

I. nil plants inoculated with the sap of the lower leaves of the sweet potato exhibited faint vein-clearing that was followed by mottling and curling. These plants were proved to be doubly infected with SPFMV and SPSV by a protein A sandwich-ELISA (PAS-ELISA). However, the intensity of the reaction in the PAS-ELISA of this SPFMV isolate with SPFMV-specific antiserum was considerably weaker than that of Mo. I. nil plants were inoculated with the sap of leaves of $I$. nil plants infected only with the virus that reacted weakly with the antiserum against SPFMV. The plants developed typical vein-clearing on the first true leaves 6-7 days after inoculation and this was followed by mottling, veinal chlorosis and chlorotic spots.

The isolate was distinguished from Mo on the basis of the distinct vein-clearing on the first true leaves of $I$. nil. This isolate was designated VC.

\section{Host range}

Herbaceous plants, including 29 species of 10 families, were mechanically inoculated with the sap of $I$. nil infected with VC. After about 20 days, the inoculated leaves as well as upper leaves were sap-inoculated to $I$. nil in order to check for latent infection. The results are shown in Table 1 . The host range of VC was limited to Ipomoea spp., Chenopodium amaranticolor and C. quinoa. No infection was obtained with Spinacia oleracea (Atlas), Nicotiana tabacum (White Burley, Samsun, Havana, Xanthi), N. benthamiana, $N$. glutinosa, $N$. debney, Datura stramonium, Physalis floridana, Lycopersicon esculentum

Table 1. Susceptible hosts and symptoms of infection by VC

\begin{tabular}{lcl}
\hline \hline & & \\
\cline { 2 - 3 } Host species & Symptoms $^{\text {a) }}$ & \\
\cline { 2 - 3 } Ipomoea nil & 1 & Uninoculated leaves \\
I. setosa & 1 & VC, Mo, VCh, CS \\
I. purpurea & 1 & VC, Mo, VCh \\
I. triloba & 1 & VC, Mo \\
I. lacunosa & 1 & VC, VCh \\
Chenopodium quinoa & $\mathrm{CS}$ & $\mathrm{VC}, \mathrm{VCh}$ \\
C. amaranticolor & $\mathrm{CS}$ & - \\
\hline
\end{tabular}

a) VC, vein clearing; Mo, mosaic ; VCh, veinal chlorosis; CS, chlorotic spot ; 1 , latent infection ; -, no infection. 


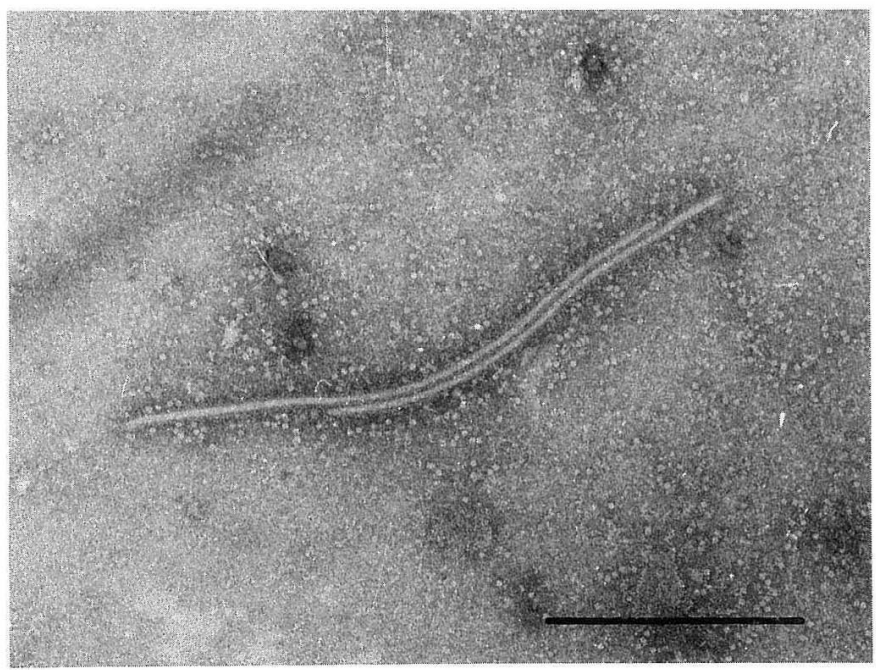

Fig. 1. Electron micrograph of particles of VC in the sap of infected Ipomoea nil leaves, stained with $2 \%$ phosphotungstic acid ( $\mathrm{pH} 7.0$ ). Bar represents $500 \mathrm{~nm}$.

(Kyoryoku Beiju), Capsicum annuum (New Face), Glycine max (Okuhara Wase), Pisum sativum (Kinusaya), Vicia faba (Sanuki Nagasaya), Phaseolus vulgaris (Top Crop), Vigna sesquipedalis (Kurodane Sanjaku), Sesamum indicum (Kurogoma), Zea mays, Tetragonia expansa, Gomphrena globosa, Raphanus sativus (Tokinashi), Citrullus lanatus (Zuishin), Cucumis sativus (Kinpyo) and Cucurbita maxima (Tetsu Kabuto).

\section{Stability in the sap of I. nil}

The infectivity of VC was lost at dilutions between $1: 10,000$ and $1: 100,000$ and after storage for one day at $20^{\circ} \mathrm{C}$. The thermal inactivation point was between $50-60^{\circ} \mathrm{C}$.

\section{Transmission by aphids}

VC was easily transmitted in a non-persistent manner from $I$. nil to $I$. nil by $M$. persicae. The same clone of $M$. persicae also easily transmitted Mo, which had not been transmitted by other clones, from I. nil to $I$. nil (data not shown).

\section{Particle length}

Electron microscopy of negatively stained leaf extracts revealed that the particles of $\mathrm{VC}$ were more flexuous than those of Mo and that the particle-length distribution of VC was between $850-880 \mathrm{~nm}$ and $13 \mathrm{~nm}$ in width, and was almost the same as that of $\mathrm{Mo}^{18)}$ (Fig. 1).

\section{Purification}

After $\mathrm{CsCl}$ equilibrium density-gradient centrifugation, two opalescent bands were observed near the bottom of each tube, and a yellowish brown pellet, considered to be due to host materials, was observed at the bottom of the tube. The upper band was faint and broad and the lower band was clear. The lower band was shown by electron microscopy to contain a large number of virus particles. The purified preparations showed low infectivity with respect to $I$. nil although the supernatant after treatment with 1-butanol had high infectivity. The method described by Cali and Moyer ${ }^{3)}$ was not chosen for purification of $\mathrm{VC}$ because no clear band was formed after $\mathrm{CsCl}$ equilibrium density-gradient centrifugation, and a considerable loss of virus particles due to aggregation occurred during differential centrifugation.

\section{Serology}

The antiserum against VC had a homologous titer of $1 / 160$ in the complement fixation test after absorption with healthy plant components. VC and Mo were found to be closely related serologically. The cross-absorption test revealed that the two viruses had common antigenic determinants as well as different ones (Table 2). No serological relationship was observed among VC, SPLV and SPSV (data not 
Table 2. Serological cross-absorption tests with VC and Mo

\begin{tabular}{|c|c|c|c|c|}
\hline \multirow{2}{*}{ Antiserum } & \multirow{2}{*}{$\begin{array}{l}\text { Absorption } \\
\text { antigen }\end{array}$} & \multicolumn{3}{|c|}{ Test antigens } \\
\hline & & $\mathrm{VC}$ & Mo & $\mathrm{H}^{\mathrm{a})}$ \\
\hline \multirow[t]{3}{*}{$\mathrm{VC}$} & - & $160^{\mathrm{b})}$ & 80 & $0^{\text {c) }}$ \\
\hline & Mo & 80 & 0 & 0 \\
\hline & $\mathrm{VC}$ & 0 & 0 & 0 \\
\hline \multirow[t]{3}{*}{ Mo } & - & 160 & 320 & 0 \\
\hline & $\mathrm{VC}$ & 0 & 80 & 0 \\
\hline & Mo & 0 & 0 & 0 \\
\hline
\end{tabular}

a) Components of healthy 1 . nil.

b) Reciprocals of the dilution endopoints of the antisera in the complement fixation test.

c) Absence of reaction with antisera diluted $1: 40$.

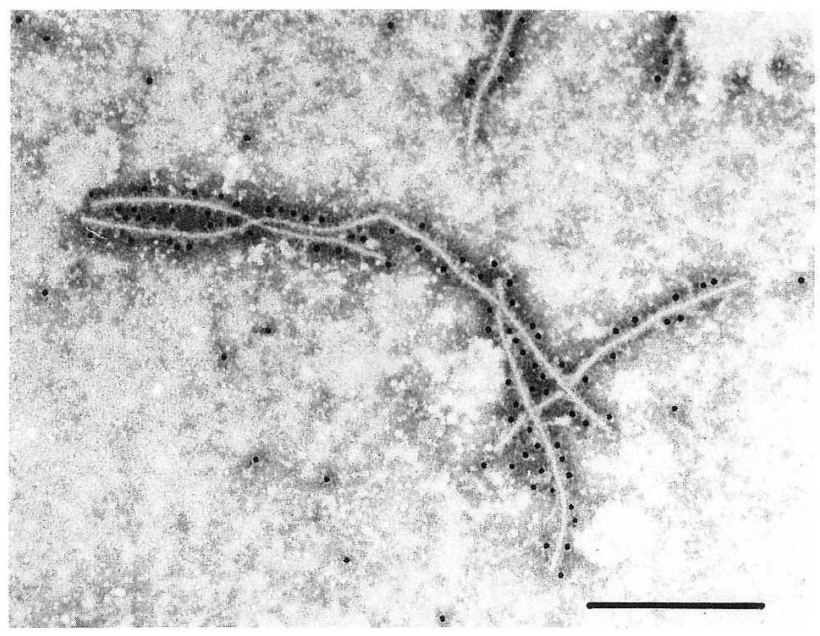

Fig. 2. Electron micrograph of the serological reaction of $\mathrm{VC}$ with its homologous antiserum by serologically specific electron microscopy using protein A-gold (SSEM-PAG). Bar represents $500 \mathrm{~nm}$.

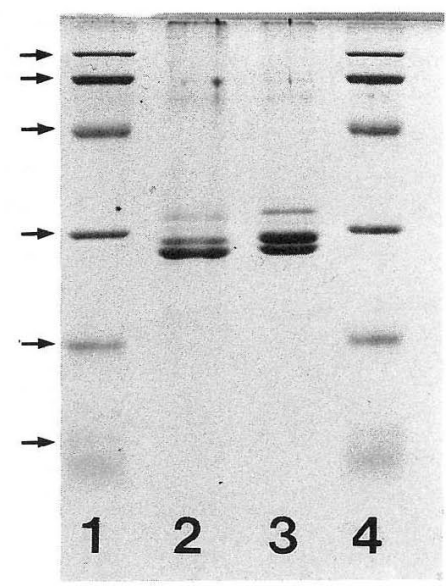

Fig. 3. Electrophoresis of coat proteins of purified Mo and VC on $5 \%$ and $15 \%$ discontinuous SDSpolyacrylamide gels. Lanes 1 and 4, marker proteins, from the uppermost band: rabbit muscle phosphorylase b (Mr 97,400), bovine serum albumin (66,200), hen egg white ovalbumin $(45,000)$, bovine carbonic anhydrase $(31,000)$, soybean trypsin inhibitor $(21,500)$ and hen egg white lysozyme $(14,400)$. Arrows indicate the positions of marker proteins. Lane 2, coat proteins of $\mathrm{VC}$; lane 3, coat proteins of Mo. 
shown). In SSEM-PAG, many virus particles were found to be trapped and densely decorated with $\gamma$-globulin molecules and gold particles when homologous antiserum was used (Fig. 2). Trapped virus particles of $\mathrm{VC}$ with its homologous antiserum had a tendency to form aggregates. When the homologous antiserum to Mo was used, many particles of VC were trapped but scattered, and gold particles were sparsely attached to the surface of the virus particles that decorated with $\gamma$-globulin molecules.

\section{Coat protein}

Coat proteins prepared from both purified VC and Mo migrated as three major bands of Mr 32,000, 30,000 and 29,000, by SDS-PAGE, as shown in Fig. 3.

\section{Electro-blot immunoassay}

Viral coat proteins in leaf homogenates of $I$. nil and I. setosa infected with Mo and VC were examined by an electro-blot immunoassay. One major protein of $\mathrm{Mr} 38,000$ and a more slowly migrating protein of $\mathrm{Mr} 97,000$, which were not detected in healthy plants, were found in the preparation of VC, and one major protein of Mr 38,000 was observed in the preparation of Mo (Fig. 4).

Samples at each step of the procedure for purification of VC were examined by the electro-blot immunoassay. Only the protein of $\mathrm{Mr} 38,000$ was clearly detectable in homogenates of infected tissues

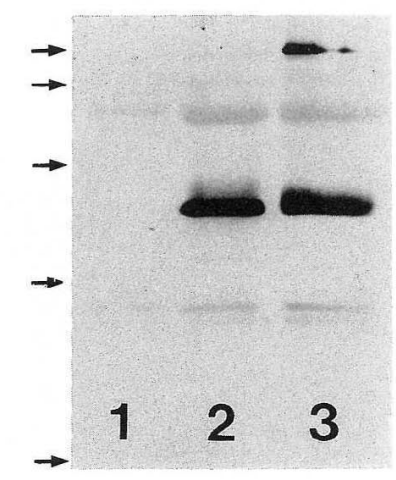

Fig. 4. Electro-blot immunoassay of coat proteins of Mo and VC in leaf homogenates. Proteins in the leaf homogenates were separated by SDS-PAGE, blotted onto a nitrocellulose membrane, and then probed with the antiserum against VC. Lane 1, homogenate of healthy $I$. nil leaf; lane 2, homogenate of leaf infected with Mo; lane 3, homogenate of leaf infected with VC. Arrows indicate the position of marker proteins. See legend to Fig. 3 for details (hen egg white lysozyme was not included here).

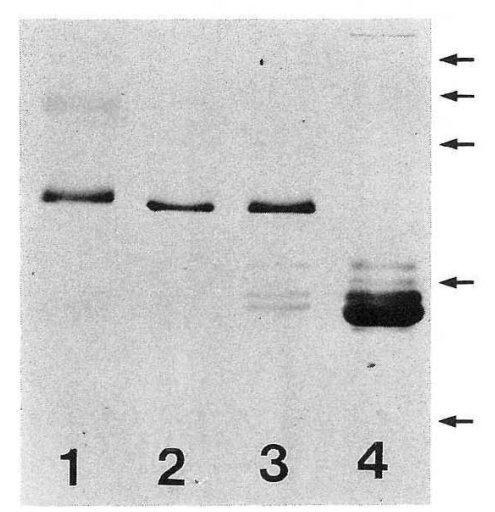

Fig. 5. Electro-blot immunoassảy of preparations of $\mathrm{VC}$ at each step in the purification. Lane 1, homogenate of infected tissues; lane 2, supernatant after 1-butanol treatment; lane 3, partially purified preparation after one cycle of differential centrifugation; lane 4, purified preparation after $\mathrm{CsCl}$ equilibrium density-gradient centrifugation. Arrows indicate the position of marker proteins. See legend to Fig. 3 for details (hen egg white lysozyme was not included here). 
Table 3. Relationship between the occurrence of russet crack on fleshy roots of sweet potato (cv. Kotobuki No. 1) and various inocula

\begin{tabular}{lcc}
\hline \hline \multicolumn{1}{c}{ Inoculum $^{\text {a) }}$} & $\begin{array}{c}\text { No. of plants } \\
\text { inoculated }\end{array}$ & $\begin{array}{c}\text { No. of plants with } \\
\text { russet crack }\end{array}$ \\
\hline VC & 37 & 25 \\
VC+SPSV & 7 & 4 \\
VC+SPLV & 6 & 5 \\
VC+Mo & 8 & 6 \\
VC+Mo+SPSV+SPLV & 5 & 1 \\
SPLV+SPSV & 8 & 0 \\
Mo+SPSV & 13 & 0 \\
Mo+SPSV+SPLV & 7 & 0 \\
Not inoculated & 5 & 0 \\
\hline
\end{tabular}

a) I. nil plants infected with the respective inocula were grafted to vines of virus-free sweet potato. SPSV: sweet potato symptomless virus. SPLV: sweet potato latent virus.

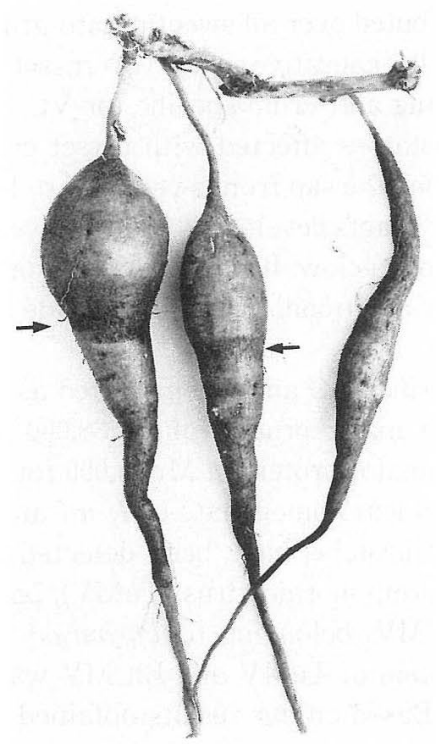

Fig. 6. Symptoms of russet crack on fleshy roots of virus-free sweet potato (cv. Kotobuki No. 1) inoculated with VC. Arrows indicate transverse bands composed of fine longitudinal cracks.

and in the supernatant after treatment with 1-butanol, while proteins of $\operatorname{Mr} 32,000,30,000$ and 29,000 in addition to the major protein of $\mathrm{Mr} 38,000$, appeared in the analysis of samples after one cycle of differential centrifugation. Furthermore, in the purified preparation after $\mathrm{CsCl}$ equilibrium densitygradient centrifugation, the intensity of the main band of the protein of $\mathrm{Mr} 38,000$ decreased very considerably and the intensities of bands of proteins with Mr 30,000 and 29,000 (major bands) and of 32,000 and 31,000 (minor bands) increased (Fig. 5).

\section{Inoculation of sweet potato}

Many chlorotic spots appeared on the newly developed and fully expanded leaves of the sweet potato plants (cv. Kotobuki No. 1) after inoculation with VC. Purple rings were occasionally observed around the chlorotic spots. Subsequently, foliar symptoms became less clear.

Typical symptoms of russet crack appeared on the fleshy roots of sweet potato after inoculation with VC alone, as well as with mixed inocula including VC. However, no symptoms were observed when plants were inoculated with inocula without VC, as previously reported (Table 3$)^{18}{ }^{18}$. Sweet potato, which had been incubated for 2-3 months in a greenhouse after graft-inoculation, developed a few transverse bands composed of fine brown longitudinal cracks on the surface of its fleshy roots (Fig. 6). Some of the 
fleshy roots, one year after inoculation, were entirely covered with cracks. No apparent effects of mixed infection by Mo, SPLV and SPSV on the expression of symptoms of russet crack were observed.

\section{DISCUSSION}

$\mathrm{VC}$ is slightly different from Mo in some respects. For instance, the isolates have different antigenic determinants in addition to common ones. $I$. nil infected with VC developed conspicuous vein-clearing on the first true leaves, which was followed by obvious mottling, but plants infected with Mo developed rather vague mottling. Mo could be purified by the method described by Cali and Moyer ${ }^{3}$, whereas this method was unsuitable for purification of VC. VC caused russet crack on the fleshy roots of sweet potato while Mo failed to induce this disease. These results indicate that VC is a new strain of SPFMV and is the causative agent of russet crack that occurs in some Japanese cultivars of sweet potato. This conclusion coincides with the previous observations that the disease is transmitted by aphids and is closely associated with a filamentous virus ${ }^{11}$.

In our previous study, we were unable to isolate $\mathrm{VC}$ from russet crack-affected sweet potatoes ${ }^{18)}$. SPFMV is known to be widely distributed over all sweet potato-growing areas in Japan. The ubiquitous nature of SPFMV, which is not the causative agent of russet crack, is likely to have hindered identification of VC. SSEM-PAG using antiserum specific for VC, which had been absorbed previously with Mo, revealed that all sweet potatoes affected with russet crack contain $\mathrm{VC}$, as far as has been tested (Usugi, unpublished data). When the sap from sweet potato leaves, which was the original source of $\mathrm{VC}$, was inoculated into $I$. nil, the plants developed only faint vein-clearing on the first of second true leaves and the frequency of infection was low. It was difficult to purify VC by the method used for Mo. These characteristics of $\mathrm{VC}$ might be additional factors that made it difficult to distinguish VC from Mo in doubly infected samples.

Coat proteins prepared from purified VC and Mo migrated as three bands of $\operatorname{Mr} 32,000,30,000$ and 29,000 by SDS-PAGE. However, one major protein of $\mathrm{Mr} 38,000$ and a faint, more slowly migrating protein of $\mathrm{Mr} 97,000$ for $\mathrm{VC}$ and one major protein of $\mathrm{Mr}$ 38,000 for Mo were detected by an electro-blot immunoassay of viral coat protein in leaf homogenate of $I$. nil and $I$. setosa infected with VC and Mo. More than two components of coat proteins have been detected in purified preparations of dasheen mosaic virus, pepper mottle virus, turnip mosaic virus (TuMV), potato virus $\mathrm{Y}$, tobacco etch virus and blackeye cowpea mosaic virus (BlCMV) belonging to Potyvirus ${ }^{2,4,6,7,9,10,13,14)}$. The component with the larger molecular weight of coat protein of TuMV and BlCMV was degraded into smaller ones during storage in a refrigerator at $4^{\circ} \mathrm{C}^{9,10}$. Based on our results obtained by electro-blot immunoassay of VC preparation at each step in the purification, components of Mr 32,000-29,000 were assumed to be derived from proteolytic degradation of protein of $\mathrm{Mr} 38,000$ during purification. The molecular weight of coat proteins of $\mathrm{VC}$ and Mo calculated from the amino acid sequences deduced from base sequences of the nucleic acid coding for coat protein were 35,173 and 35,235 , respectively ${ }^{12)}$. Although the $\mathrm{Mr} 38,000$ estimated by SDS-PAGE is slightly larger than the calculated value, the protein of $\mathrm{Mr} 38,000$ is considered to be the intact coat protein. Purified preprations after $\mathrm{CsCl}$ density-gradient centrifugation lost almost all infectivity. It is not clear whether the partial degradation of coat protein is related to the loss of infectivity.

SPFMV-russet crack strain (SPFMV-RC), which is the causative agent of russet crack disease in the U.S.A., seems to be slightly different from $\mathrm{VC}^{3,5)}$. Reaction of $\mathrm{VC}$ with antiserum against SPFMV-RC in PAS-ELISA was weaker than that of $\mathrm{Mo}^{19}$. VC could not be purified by the method used for SPFMV-RC ${ }^{3)}$. Furthermore, differences between SPFMV-RC and VC in amino acid residues in the capsid proteins, whose sequences were deduced from base sequences of the nucleic acids, were found at positions 13, 20 and 76 from the N-terminus ${ }^{1,12}$. SPFMV-common strain, which is reported in U.S.A., is apparently different from VC and Mo in terms of symptomatology of I. purpurea, C. quinoa and C. amaranticolor $^{3)}$. From the present and previous observations ${ }^{18)}$, we named $\mathrm{VC}$ and Mo severe strain of SPFMV (SPFMV-S) and ordinary strain of SPFMV (SPFMV-O), respectively. 
The authors wish to thank Mr. R. Nagata, Miyazaki Agricultural Experiment Station, Miyazaki, Japan, for supplying healthy and diseased fleshy roots of sweet potato.

\section{Literature cited}

1. Abad, J.A., Conkling, M.A. and Moyer, J.W. (1992). Comparison of the capsid protein cistron from serologically distinct strains of sweet potato feathery mottle virus (SPFMV). Arch. Virol. 126: 147-157.

2. Abo El-Nil, M.M., Zettler, F.W. and Hiebert, E. (1977). Purification, serology, and some physical properties of dasheen mosaic virus. Phytopathology 67 : 1445-1450.

3. Cali, B.B. and Moyer, J.W. (1981). Purification, serology, and particle morphology of two russet crack strains of sweet potato feathery mottle virus. Phytopathology $71: 302-305$.

4. Choi, J.K. and Wakimoto, S. (1979). Characterization of the protein components of turnip mosaic virus. Ann. Phytopath. Soc. Japan $45: 32-39$.

5. Daines, R.H. and Martin, M.J. (1964). Russet crack, a new virus disease of sweet potatoes. Plant Dis. Rep. 48: 149-151.

6. Hiebert, E. and McDonald, J.G. (1973). Characterization of some proteins associated with viruses in the potato Y group. Virology $56: 349-361$.

7. Hiebert, E. and McDonald, J.G. (1976). Capsid protein heterogeneity in turnip mosaic virus. Virology 70 : 144-150.

8. Laemmli, U.K. (1970). Cleavage of structural proteins during the assembly of the head of bacteriophage T4. Nature $227:$ 680-685.

9. Lima, J.A.A., Purciful, D.E. and Hiebert, E. (1979). Purification, partial characterization, and serology of black-eye cowpea mosaic virus. Phytopathology 69 : 1252-1258.

10. Michelin-Lausarot, P. and Papa, G. (1975). The coat protein of the alliaria strain of turnip mosaic virus: molecular weight and degradation products formed during purification and upon storage. J. Gen. Virol. 29 : 121-126.

11. Nagata, R. (1984). Transmission of russet crack-like symptom by grafting to sweet potato grown from apical meristem tips. Proc. Assoc. Pl. Prot. Kyushu $30: 33-35$ (in Japanese).

12. Nishiguchi, M. and Mori, M. (1992). Biotechnology for virus diseases of sweet potato. Shokubutsu Boeki (Plant Prot.) $46:$ 241-244 (in Japanese).

13. Okuda, S., Hasegawa, M., Natsuaki, T., Kaji, K., Natsuaki, K.T. and Teranaka, M. (1992). Clover yellow vein virus isolated from bean (Phaseolus vulgaris) showing vine necrosis in Fukushima Prefecture. Ann. Phytopath. Soc. Japan 58: 298-304 (in Japanese).

14. Shimoyama, J., Hanada, K., Tsuda, S., Kameya-Iwaki, M. and Gunji, T. (1992). Some physicochemical and serological properties of konjak mosaic virus and dasheen mosaic virus. Ann. Phytopath. Soc. Japan 58: 713-718 (in Japanese).

15. Shinkai, A., Matsuda, S. and Iwahashi, T. (1980). Occurrence of russet crack-like disease in sweet potato. Ann. Phytopath. Soc. Japan $46: 67$ (Abstr. in Japanese).

16. Usugi, T., Maoka, T. and Hayashi, T. (1992). Purification and serological properties of sweet potato feathery mottle virus severe strain. Ann. Phytopath. Soc. Japan 58: 615-616 (Abstr. in Japanese).

17. Usugi, T., Nakano, M., Onuki, M. and Hayashi, T (1990). A filamentous virus causative of "Obizyo-sohi" disease on fleshy root of sweet potato. Ann. Phytopath. Soc. Japan 56: 423 (Abstr. in Japanese).

18. Usugi, T., Nakano, M., Shinkai, A. and Hayashi, T. (1991). Three filamentous viruses isolated from sweet potato. Ann. Phytopath. Soc. Japan $57: 512-521$.

19. Usugi, T., Onuki, M. and Hayashi, T. (1990). Detection of some viruses by protein A sandwich ELISA (PAS-ELISA). Kyushu Agric. Res. 53 : 106 (in Japanese).

\section{和 文 摘 要}

宇杉富雄・中野正明・大貫正俊・真岡哲夫・林 隆治：わが国のサツマイモ塊根に帯状粗皮症状を示すサツマイモ斑 紋モザイクウイルスの新系統

帯状粗皮病に対して抵抗性を示すサツマイモより新しくひも状ウイルスが分離された。本ウイルス (VC 分離株) は 数種の Ipomoea 属植物, Chenopodium quinoa およびC. amaranticolor に感染した。感染アサガオは第一本葉に典型 的な葉脈透化を示した。本ウイルス感染アサガオ葉汁液の希釈限界は $10,000 \sim 100,000$ 倍, 不活化温度は $50 \sim 60^{\circ} \mathrm{C}$, 保 存限界は 1 日以内であった。ウイルス粒子は長さ 850 ～ $880 \mathrm{~nm}$ で幅 $13 \mathrm{~nm}$ であった。本ウイルスはモモアカアブラム シによって非永続的に伝搬され，サツマイモ斑紋モザイクウイルス (SPFMV, Mo 分離株) との間で血清学的類縁関 
係が認められたが, 同一ではなかった。ポリアクリルアミドゲル電気泳動の結果, 純化 VC および Mo の外被タンパク

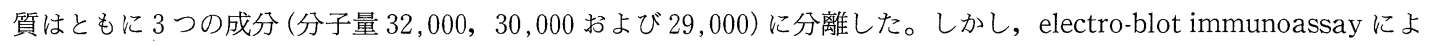
り VC 感染葉では分子量 38,000 の主なバンドと分子量 97,000 のバンドが, Moでは分子量 38,000 のバンドが認めら れた。VCを単独で無毒のサツマイモに接種したところ塊根に典型的な带状粗皮症状が認められた。これらの結果は VC は帯状粗皮病の病原ウイルスであり, SPFMV の新しい系統であることを示している。ここにVC および Mo をそ れぞれ SPFMV 強毒系統（severe strain）および普通系統（ordinary strain）と命名したい。 